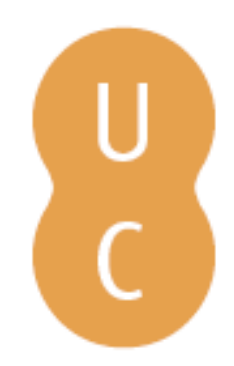

\title{
nombalina
}

\section{Estética alimentar queirosiana: notas gastronómicas na obra de Eça de Queirós}

\author{
Autor(es): $\quad$ Peixinho, Ana Teresa
}

Publicado por: Imprensa da Universidade de Coimbra; Annablume

URL

persistente: $\quad$ URI:http://hdl.handle.net/10316.2/39618

DOI: $\quad$ DOl:https://doi.org/10.14195/978-989-26-1191-4_9

Accessed : $\quad$ 26-Apr-2023 14:33:18

A navegação consulta e descarregamento dos títulos inseridos nas Bibliotecas Digitais UC Digitalis, UC Pombalina e UC Impactum, pressupõem a aceitação plena e sem reservas dos Termos e Condições de Uso destas Bibliotecas Digitais, disponíveis em https://digitalis.uc.pt/pt-pt/termos.

Conforme exposto nos referidos Termos e Condições de Uso, o descarregamento de títulos de acesso restrito requer uma licença válida de autorização devendo o utilizador aceder ao(s) documento(s) a partir de um endereço de IP da instituição detentora da supramencionada licença.

Ao utilizador é apenas permitido o descarregamento para uso pessoal, pelo que o emprego do(s) título(s) descarregado(s) para outro fim, designadamente comercial, carece de autorização do respetivo autor ou editor da obra.

Na medida em que todas as obras da UC Digitalis se encontram protegidas pelo Código do Direito de Autor e Direitos Conexos e demais legislação aplicável, toda a cópia, parcial ou total, deste documento, nos casos em que é legalmente admitida, deverá conter ou fazer-se acompanhar por este aviso.

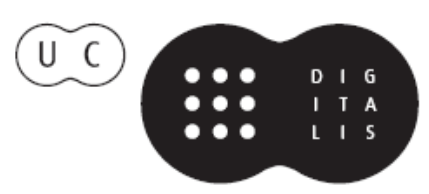




\title{
Estética ALIMENTAR QUEIROSIANA: NOTAS GASTRONÓMICAS NA OBRA DE EÇA DE QUEIRóS ${ }^{1}$ Food aesthetics: culinary notes on the work of Eça de Queirós
}

\author{
Ana Teresa Peixinho \\ Universidade de Coimbra, Faculdade de Letras, CEIS20 \\ apeixinho71@gmail.com
}

Resumo: A grande maioria das obras de Eça de Queirós consagram um espaço significativo às referências alimentares, como tem sido assinalado pela crítica. Almoços e jantares, espaços de convivialidade, pratos e iguarias são minuciosamente descritos, com especial atenção à decoração, aos menus, aos sabores e fragrâncias. Contudo, quando se alarga o foco de análise, percebe-se que mesmo em textos menores, nomeadamente em cartas e crónicas de imprensa, a presença desta temática é uma constante. Pretende-se, neste breve texto, revisitar algumas dessas referências, tentando demonstrar como a presença do alimento nas narrativas ecianas ultrapassa o mero apontamento decorativo ou mesmo a simples notação realista. Sobretudo ao nível da figuração das suas personagens e no desenvolvimento de temáticas nucleares, o alimento é crucial na estética do romancista.

Palavras-Chave: Alimentação - literatura - personagem - Eça de Queirós

Aвstract: The vast majority of the works by Eça de Queirós devote significant space to references to food, as critics have pointed out. Lunches and dinners, convivial spaces, dishes and delicacies are thoroughly described, with special attention to decor, menus, flavors and fragrances. However, when one broadens the focus of analysis, it is clear that even in shorter texts, including letters and press chronicles, the presence of this theme is a constant. It is intended, in this brief text, to revisit some of these references by trying to demonstrate how the presence of food in the narratives by this author goes beyond the mere decorative note or even simple realistic notation. Particularly in terms of the construction of his characters and the development of nuclear topics, food is crucial in the novelist's aesthetics.

KEYwords: Food, literature, character, Eça de Queirós

${ }^{1}$ Texto que resulta de uma conferência proferida em dezembro de 2014, na Casa da Escrita, em Coimbra, integrada no ciclo de palestras "Saberes e sabores" coorganizado pelo DIAITA e pela CMC. 


\section{A Significação mitológica da Alimentação}

"O Vinho e o Leite" e "Bife e Batatas Fritas" são os títulos de dois interessantes ensaios que Roland Barthes publicou no final da década de 50 do século passado, no jornal francês Les Lettres Nouvelles, e que posteriormente reuniu no livro Mitologias, obra revolucionária que marcou a abertura da semiologia a campos tão diversos como a publicidade, o cinema, a moda ou os objetos de uso diário. Nestes textos, Barthes demonstra como a gastronomia deve ser lida também ela, a par de muitos outros produtos da sociedade de massas, como um mito da sociedade burguesa, transcendendo a sua condição de objeto quotidiano, para passar a funcionar como reflexo do mundo e das estruturas ideológicas e políticas das sociedades. Neste contexto, o bife, as batatas fritas, o vinho ou o leite são lidos como marcas identitárias de uma sociedade e funcionam como falas próprias - no sentido saussureano do termo - de línguas culturalizadas e partilhadas historicamente.

Aquilo que é demonstrado pelas leituras do semiólogo francês compagina-se com a valorização cultural e semiológica da alimentação como fenómeno ancestral. De facto, a atividade gastronómica está ligada a raízes históricas, geográficas, ambientais e patrimoniais, como tem sido sobejamente demonstrado ao longo dos tempos, por áreas disciplinares tão variadas quanto a Antropologia, a Psicologia, os Estudos Culturais ou a Teoria Semiótica. Alimentarmo-nos representa muito mais do que uma atividade fisiológica essencial à vida, é um ato de incontestável dimensão cultural: os alimentos carreiam significados, são portadores de imagens simbólicas, representam comportamentos coletivamente imaginados que permitem entender a alimentação como uma verdadeira linguagem. São, se quisermos utilizar um conceito barthesiano, uma função signo complexa, cuja funcionalidade permitir a vida do ser humano - remete para outros significados secundários, estratificadamente sobrepostos.

"O homem nutre-se também de imaginário e de significados, partilhando representações coletivas. Se é possível avaliar o valor nutritivo do alimento (um combustível a ser liberado como energia e sustentar o corpo) o ato alimentar implica também em um valor simbólico, o que complexifica a questão, pois requer um outro tipo de abordagem"2.

Ramalho Ortigão, amigo e contemporâneo de Eça de Queirós, escreveu um dia que "a maneira como se cozinha marca o índice de civilização de um povo" e o próprio Eça, autor de que nos ocuparemos neste artigo, na longa crónica publicada na Gazeta de Notícias do Rio de Janeiro, em 1893 - "Cozinha

\footnotetext{
${ }^{2}$ Maciel, 2002: 2.
} 
Arqueológica" -, afirma que a cozinha é uma das manifestações que "melhor revelam o génio de uma raça" e que a "mesa constituiu sempre um dos fortes, se não o mais forte alicerce das sociedades humanas" ${ }^{3}$. De facto, a atividade gastronómica tem alimentado as páginas da literatura universal desde a Antiguidade aos nossos dias. $\mathrm{O}$ homem civilizado come não somente por fome, para satisfazer uma necessidade elementar do corpo, mas também (e sobretudo) para transformar esta ocasião num ato de sociabilidade, lembram os autores da Histoire de l'Alimentation'.

Do Banquete de Platão à "Festa de Babete" de Karen Blixen passaram centenas e centenas de anos e muito se escreveu e publicou sobre alimento, bebida, gastronomia. Num artigo recente, Maria Alzira Seixo dedica uma atenção especial a esta temática, traçando um panorama geral da representação da gastronomia na literatura. Esta, diz-nos a autora:

"remonta à Antiguidade, onde encontramos um poema do grego Arquestrato sobre a arte culinária, do séc. IV A.C., e, já no início da nossa Era, surge em Roma, no romance Satiricon, de Petrónio, onde se destaca o episódio conhecido como a Cena Trimalquionis («O Jantar de Trimalquião»), que descreve um banquete. Mas são talvez os textos bíblicos, quer no Antigo quer no Novo Testamento, que abundam em episódios relacionados com a nutrição, possuindo uma incidência particularmente moral que se liga aos intentos sociais postulados pelo Cristianismo, mas que criam uma simbologia particular. É o caso do emblemático "peixe", numa religião que tem pescadores no seu núcleo fundador, ou do privilégio concedido à "comunhão" e às refeições comunitárias. Nesses textos sagrados, muitos dos episódios centrais relacionam-se com a cerimónia de comer, adquirindo o alimento um intenso valor espiritual. É o caso da Multiplicação dos Pães, das Bodas de Canaã e, muito em especial, da Última Ceia. Tal acontece também com a literatura medieval do Ocidente, com exemplo nos Cavaleiros da Távola Redonda e algumas referências na poesia, embora os valores artísticos da época se reportem sobretudo à espiritualidade, transferindo progressivamente a alimentação para a esfera do simbólico." ${ }^{5}$

A imagem do alimento parece apropriada para estabelecer certas analogias já que também nos alimentamos da leitura, "devoramos" livros, salivamos ao ler a descrição sugestiva de um repasto ou iguaria. Já na literatura infantojuvenil, a marca simbólica do alimento está presente: da cesta cuidadosamente preparada por Capuchinho Vermelho; às migalhas de pão que João e Maria vão deixando no bosque como pistas até à casa, também ela comestível; das ceias de Ano Novo entrevistas pelas janelas das mansões da cidade pela Pequena

\footnotetext{
${ }^{3}$ Queirós, 2002: 315.

${ }^{4}$ Montanari e Frandrin, 1996.

${ }^{5}$ Seixo, 2014: 18.
} 
vendedora de fósforos faminta; ao Soldadinho de Chumbo que, depois de mirabolante viagem pelo esgoto, termina na barriga do peixe que ia à mesa. Geralmente, não há história clássica infantil que dispense a valorização de cenas de mesa ou apontamentos simbólicos do imaginário alimentar.

\section{UM TEMA DEMASIAdo RECORRENTE: EÇA E A MESA...}

A gastronomia em Eça de Queirós é um tema já amplamente estudado, debatido, divulgado e muito já se escreveu sobre os prazeres da mesa na obra do escritor. Existe mesmo um Dicionário de Gastronomia Queirosiana, da autoria de Dário Alves ${ }^{6}$, publicado há já duas décadas, e alguns roteiros de enologia lhe foram dedicados. Todos os anos, em várias universidades do mundo, são defendidas teses e dissertações académicas sobre este tema, quer no âmbito de investigações interdisciplinares do domínio da alimentação, quer no âmbito de Cursos de Literatura.

Multiplicam-se, um pouco por todo o lado, os jantares e almoços queirosianos e quem visitar, no Concelho de Baião, a Quinta onde se encontra sediada a Fundação Eça de Queiroz poderá deliciar-se com uma bela canja de galinha ou com o arroz com favas, servidos em homenagem às referências romanescas do autor de $A$ Cidade e as Serras.

A atenção que tem sido dedicada à gastronomia e à enologia queirosianas é, antes de mais, fruto do vasto espaço que elas ocupam na obra do romancista. São cerca de 4500 as alusões à comida e à bebida e os seus grandes romances possuem diversas cenas de mesa; a título de exemplo, bastará referir que, n’Os Maias, há quinze refeições completas, para além de muitas outras referências alimentares pontuais; n' $A$ Cidade e as Serras, há pelo menos seis jantares e almoços; n'A Ilustre Casa de Ramires e n'A Capital as refeições ocupam um espaço diegético bastante considerável e $O$ Crime do Padre Amaro descreve pelo menos quatro grandes refeições. É, porém, também consequência da sedução do leitor perante a habilidade estilística do romancista, que se perde em descrições quase fotográficas dos menus, das atitudes dos convivas, das sensações, dos sabores e das fragrâncias. Há páginas queirosianas que se revelam excelentes exemplos de descrições sensoriais, indo muito além do apontamento detalhado e realista, que exploram as capacidades plásticas, visuais e sensitivas da linguagem, a ponto de possibilitar a imersão do leitor nesses repastos.

Beatriz Berrini, autora da obra Comer e Beber com Eça de Queiroz, exprime assim a excecionalidade das descrições de Eça:

\footnotetext{
${ }^{6}$ Alves, 1992.
} 
"raros são os escritores dotados de uma expressão de linguagem tão investida de valores sensoriais como Eça de Queirós. De tal maneira que, na verdade, o leitor não somente vê diante de si um prato deleitoso mas ainda irá saboreá-lo com emudecida admiração garfada por garfada, acompanhando com um saboroso vinho essa refeição naturalmente abstrata, que não lhe mata a fome; concreta porém no sentido que através da leitura apreende os sabores e os prazeres que o texto queirosiano lhe proporciona." ${ }^{7}$

Esta excessiva atenção à comida e aos atos de comensalidade foi alvo da crítica de Machado de Assis que chegou a considerar, na dura crítica que faz a O Primo Basílio, uma fartura desnecessária as alusões, descrições e detalhes sobre cozinha, alimentos e repastos ${ }^{8}$. Contudo, mais recentemente, alguns estudiosos começaram a chamar a atenção para o alcance desses "excessos" nesse amplo projeto de representação da sociedade portuguesa ensaiada pela obra de Eça: Andrée Rocha (1988), Isabel Pires de Lima (1997), Beatriz Berrini (1995; 1997; 2014) e Ana Luísa Vilela (2010 e 2012) notaram que o tratamento zeloso da comida não foi, como duramente opinou Machado de Assis, um exagero de escola realista. Nas narrativas ecianas, as cenas gastronómicas têm funções diegéticas e ideológicas relevantes, que vão muito além da mera descrição realista, estruturando o ambiente moral e material, servindo a figuração das personagens, o desenvolvimento das narrativas e o exercício da crítica e da sátira. Assim, pode dizer-se que a cozinha organiza o universo narrativo dos romances de Eça e revela uma importante possibilidade de interpretação do seu projeto de representação da sociedade portuguesa, conclui José de Andrade, em artigo dedicado às potencialidades romanescas das referências alimentares no Primo Basílio ${ }^{\circ}$.

Eça transpõe, com a mestria que lhe é característica, sabores que certamente a experiência pessoal lhe terá proporcionado e é no mínimo espantosa a riqueza vocabular: o leque de verbos - devorar croquetes, tragar um colares, atolar os dentes num figo, rilhar um bife-, a vasta gama de adjetivos e de figuras de estilo usadas para construir os quadros de referência alimentar, adaptando

${ }^{7}$ Berrini, 1995: 162-163.

8 "Quanto à preocupação constante do acessório, bastará citar as confidências de Sebastião a Julião, feitas casualmente à porta e dentro de uma confeitaria, para termos ocasião de ver reproduzidos o mostrador e as suas pirâmides de doces, os bancos, as mesas, um sujeito que lê um jornal e cospe a miúdo, o choque das bolas de bilhar, uma rixa interior, e outro sujeito que sai a vociferar contra o parceiro; bastará citar o longo jantar do Conselheiro Acácio (transcrição do personagem de Henri Monier); finalmente, o capítulo do Teatro de São Carlos, quase no fim do livro. Quando todo o interesse se concentra em casa de Luísa, onde Sebastião trata de reaver as cartas subtraídas pela criada, descreve-nos o autor uma noite inteira de espetáculos, a plateia, os camarotes, a cena, uma altercação de espectadores" (Assis, 1994: s/p).

${ }^{9}$ Andrade, 2014. 
com muita precisão o vocabulário aos contextos, ao perfil das personagens, ao tipo de manjares descritos e à dinâmica narrativa.

Num século em que, em Portugal, o público e o privado se começam a definir, o espaço das refeições era muito valorizado: quer como espaço de reunião privada em família, quer como espaço de convivialidade social. "Ainda hoje - comenta Eça em "Cozinha Arqueológica" - se não cria um grémio, ou um sindicato, sem que os sócios jantem, cimentando os estatutos com champanhe e túbaras." ${ }^{10}$ Afinal, não integrou o próprio Eça o grupo jantante de os Vencidos da Vida? ${ }^{11}$

Embora seja a partir da década de 70 , com a progressiva afirmação do Realismo, que o momento de comer dá origem, na ficção oitocentista nacional, a episódios descritivos ricos em pormenor e de importância decisiva no desenrolar das estórias, como se verifica em diversas obras de Júlio Dinis, Camilo Castelo Branco e até na poesia de Cesário Verde, Eça desde sempre revelou especial atenção a esta dimensão cultural do quotidiano.

Começamos por centrar a nossa atenção em textos menos divulgados, de estatuto mais marginal, onde as referências à alimentação, à cozinha e à gastronomia ocupam também um espaço considerável e nos ajudam a perceber que a alimentação não é exclusiva dos grandes romances da maturidade, tendo sido desde sempre objeto de atenção por parte do escritor, como fenómeno cultural e sociológico importante, inclusive na sua epistolografia privada, sobretudo quando se queixa do isolamento, da distância e da ausência. Em carta dirigida ao amigo Bernardo - o Conde de Arnoso - em 1885, a partir de Bristol, queixa-se de viver numa sociedade "em que tudo lhe é desagradável - desde a sua estreita maneira de pensar até ao seu indecente modo de cozer os legumes" ${ }^{12}$.

Pedindo de empréstimo uma expressão usada por Carlos Reis, quando desafiado a refletir sobre a sua queirosiana mínima:

"Deixo, então, de lado, por agora, as "grandes relíquias" queirosianas e curo das mínimas relíquias: pequenas reflexões, observações avulsas, memórias recônditas.

${ }^{10}$ Queirós, 2002: 316.

${ }^{11}$ Como é do conhecimento geral, trata-se de um grupo de onze homens, entre eles alguns bem conhecidos da vida cultural portuguesa, como Guerra Junqueiro, Carlos Mayer, Ramalho Ortigão, Oliveira Martins e, naturalmente, Eça de Queirós, que durante dois anos organizavam umas reuniões "jantantes” onde confraternizavam e, naturalmente, discutiam assuntos vários. Eça de Queirós publicou no jornal O Tempo, a 29 de março de 1889, um texto que visava explicar, com muita ironia, que grupo era esse que tanta publicidade gerava na imprensa: "O que de resto parece irritar o nosso caro CORREIO DA MANHÃ é que se chamem vencidos àqueles que para todos os efeitos públicos parecem ser realmente vencedores. Mas que o querido órgão, nosso colega, reflita que para um homem, o ser vencido ou derrotado na vida depende, não da realidade aparente a que chegou - mas do ideal íntimo a que aspirava." (Queirós, 2006: 34).

${ }^{12}$ Queirós, 1983: 255. 
Noutros termos: o meu Eça é feito também de queirosianismos minimos como os que aqui ficam. O meu Eça e os meus Eças." ${ }^{13}$

\section{A gastronomia em Eça}

Muito jovem ainda, assumindo as funções quase profissionais de um jornalista de província, Eça deixa em alguns textos do Distrito de Évora algumas notações alimentícias: quer porque se obrigava a noticiar a carestia da vida e elencava os preços dos víveres básicos, quer porque necessitava de colorir hábitos e costumes locais, quer ainda porque, fazendo a alimentação parte da vida quotidiana, por ela passam algumas das notícias e crónicas do Distrito.

Assumindo a pele de um "verdadeiro" jornalista, Eça dá informações precisas e úteis sobre questões agrícolas e comerciais, a ponto de a leitura de algumas das suas páginas nos permitirem ter hoje a noção do custo do quartilho de vinho, do azeite, do toucinho, de dois arráteis e meio de carne de vaca, da manteiga de porco, ou seja, de bens alimentícios de consumo diário, típicos da dieta do povo alentejano à época, a quem eram pedidos sacrifícios imensos perante a carestia do custo de vida, num período de aguda crise financeira e económica.

Imbuído de um espírito de revolta social, bem sintomático da sua exaltada juventude, e obedecendo àquilo que acreditava ser o dever do jornalismo, Eça clamava por justiça e igualdade perante os desequilíbrios de um país muito desigual. Embora, na sua obra de maturidade, aquela que verdadeiramente se conhece e se lê, o povo não tenha uma presença significativa, já nestas páginas de jornalismo, inúmeras vezes o autor se arvora em defensor popular: o povo que faz o pão; o pão como alimento simbólico e básico suporte de vida. Embora não tenhamos contabilizado o número de ocorrências da palavra 'pão', verificamos que ela é recorrente e sistemática, sendo utilizada muitas vezes como conotação de vida, de trabalho e até, por antonomásia, de povo: "ganhar o pão", "suar o pão", "criar o pão"... como uma metonímia simbólica de alimento essencial da população mais carenciada.

Num texto sobre política nacional que escreve para o Distrito de Évora (3 de março de 1867), em que o assunto é a grave crise que grassava pelo país, Eça louva a atitude de abnegação do povo, como coletivo sempre disposto a sacrifícios pela pátria, mesmo quando estes implicavam privações de bens essenciais como a alimentação:

"Despede-se de tudo generosamente, para dar à mãe-pátria. Despede-se sem mágoa, com nobre alegria. Mas será justo que este sacrifício seja para cobrir as

${ }^{13} \mathrm{Cf}$. https://queirosiana.wordpress.com/queirosiana-minima/queirosiana-minima/ (consultado em abril de 2015). 
prodigalidades dos governos? Que se tire um pedaço do pão do pobre para dar mais uma farda a um embaixador? Que se onerem os géneros de consumo, a carne, o sal, o azeite, o arroz, o pão, para que no mundo oficial haja mais aparatos reluzentes e mais transformações feéricas?” ${ }^{14}$

O confronto entre a abundância e a privação, transposto para o contraste entre o pão e as iguarias mais fartas, é uma constante nas páginas do Distrito de Évora, sobretudo nas crónicas, e reaparece também, de modo mais elaborado, nas posteriores narrativas ficcionais.

Assim, a meio de um farto repasto, em casa do abade da Cortegaça que "passava por ser o melhor cozinheiro da diocese", o clero de Leiria deleita-se à volta de um belo capão recheado, quando um pedinte veio bater a pedir esmola e apenas teve direito a metade de uma broa seca, enquanto os padres comentam frivolamente a pobreza da região, empanturrando-se com o pitéu que rescendia:

“- Muita pobreza por aqui, muita pobreza! - dizia o bom abade. - Ó Dias, mais este bocadinho de asa! / - Muita pobreza, mas muita preguiça - considerou duramente o padre Natário. Em muitas fazendas sabia ele que havia falta de jornaleiros, e viam-se marmanjos, rijos como pinheiros, a choramingar padres-nossos pelas portas. - Súcia de mariolas! - resumiu. / - Deixe lá, padre Natário, deixe lá! - disse o abade. - Olhe que há pobreza deveras. Por aqui há famílias, homem, mulher e cinco filhos, que dormem no chão como porcos e não comem senão ervas. / - Então que diabo querias tu que eles comessem? - exclamou o cónego Dias lambendo os dedos depois de ter esburgado a asa do capão. - Querias que comessem peru? Cada um como quem é!"15

Já em O Primo Basílio, as criadas alimentam-se habitualmente mal e é revelador que as chaves da despensa sejam ciosamente guardadas por Luísa e cobiçadas por Juliana que, numa das distrações da patroa, aproveita para "beber um trago de bom vinho e engolir dois ladrilhos de marmelada." Sabemos também que, num dos passeios pela sua herdade no Douro, Jacinto fica surpreendido quando percebe que o povo, cuja arte culinária tanto o deslumbrou, passa fome, é subnutrido e apenas tem direito a umas côdeas de pão seco. Estas breves notas ilustram bem como o contraste entre a opulência e a carestia, presente em registo panfletário nas páginas juvenis de jornalismo, reaparece em romances da maturidade, em que o alimento é meio de ilustrar desequilíbrios sociais que inquietavam o escritor, embora não tenham sido suficientemente desenvolvidos e passem como breves apontamentos.

\footnotetext{
${ }^{14}$ Queirós, 1981: 207-208.

15 Queirós, 2000: 205, 207.
} 
Outra funcionalidade das referências alimentares nas páginas do jornal eborense tem que ver com a ilustração do exotismo gastronómico de outros povos e culturas. Como que antecipando aquilo que escreverá mais tarde em "Cozinha Arqueológica"16, as "reportagens internacionais" de Eça têm o cuidado de integrar, como colorido local, notas sobre hábitos, costumes e práticas alimentares:

"O caráter de uma raça pode ser deduzido simplesmente do seu método de assar a carne. Um lombo de vaca (...) faz compreender melhor as diferenças intelectuais destes povos do que o estudo das suas literaturas." ${ }^{17}$

Nas crónicas-reportagem sobre a grande Exposição Universal de Paris ${ }^{18}$, no Distrito de Évora, realça o exotismo da "suspeitosa cozinha de proveniência asiática":

"Quem responderá - pergunta o cronista - pela veracidade e frescura dos ninhos de Salangana? Não estará alterado o molho de bichos-de-conta pisados? Dizemnos que as frituras de gafanhotos são tentadoras, mas que a conserva de lagartas de couve pouco tem agradado." ${ }^{19}$

Conhecedor dos tabus alimentares e sabendo como eles poderiam gerar surpresa nos leitores, os menus selecionados da gastronomia oriental são descritos com um realismo tal, que levará o leitor mais incauto a acreditar estar perante crónicas de um correspondente exterior que, in loco, andasse degustando tais acepipes: espantoso como, sem sair de Évora, sem ter posto um pé na Grande Exposição, o jornalista consiga com tanta vivacidade acompanhar a reportagem da efeméride e comentar os exóticos petiscos orientais, tão diferentes dos pratos tradicionais da dieta nacional.

Mais tarde, quando em 1880 escreve $O$ Mandarim, abundam as notações exóticas da mesa, havendo algumas descrições da decoração das salas, dos empratamentos e da excentricidade dos petiscos:

"Nessa manhã - conta o narrador - em honra da minha nova encarnação, havia um almoço chinês. Que gentis guardanapos de papel de seda escarlate, com monstros fabulosos desenhados a negro! O serviço começou por ostras de NingPó. Exímias! Absorvi duas dúzias com um intenso regalo chinês. Depois vieram

\footnotetext{
${ }^{16}$ Esta crónica foi publicada em 13, 14 e 15 de maio de 1893, na Gazeta de Notícias do Rio de Janeiro (Queirós, 2002: 313-322).

${ }_{17}^{17}$ Queirós, 2002: 316.

${ }^{18}$ Esta exposição teve lugar em Paris e mereceu, no Distrito de Évora, ampla cobertura no espaço da "Chronica".

${ }^{19}$ Queirós, 1981: 215.
} 
deliciosas febras de barbatana de tubarão, olhos de carneiro com picado de alho, um prato de nenúfares em calda de açúcar, laranjas de Cantão, e enfim o arroz sacramental, o arroz dos Avós... Delicado repasto, regado largamente de excelente vinho de Chão-Chigne! E, por fim, com que gozo recebi a minha taça de água a ferver, onde deitei uma pitada de folhas de chá imperial, da primeira colheita de março, colheita única, que é celebrada com um rito santo pelas mãos puras de virgens!..." ${ }^{20}$

Também em $A$ Relíquia, na grande viagem ao passado, empreendida por Teodorico Raposo e o seu douto companheiro Topsius, o leitor é brindado com a descrição de uma ceia pascal, recheada de verdadeiras iguarias, das quais se destaca a entrada de cigarras fritas:

"A um lado tínhamos, para limpar os dedos, um bolo de farinha branca, fino e mole como um pano de linho; do outro, um prato largo, com cercadura de pérolas, onde negrejava, entre ramos de salsa, um montão de cigarras fritas; no chão jarros com água de rosa." ${ }^{21}$

Ainda no Distrito de Évora, um dos temas que chama a sua atenção é o concurso de vinhos, organizado na Exposição Parisiense, e onde Portugal teve uma excelente prestação, por causa dos seus Douros e Madeiras. Reconhecimento que o cronista adjetiva de "honroso", aproveitando para censurar o mundo da política: "Que ao menos sejamos grandes nalguma indústria, já que tão pequenos somos na moralidade política.” ${ }^{22}$

Se percorrermos com atenção as crónicas de imprensa de Eça de Queirós, desde o início da sua atividade de escritor, percebemos que as notações alimentícias e referências a jantares, ceias, mercados, produtos alimentares são uma constante. Em uma das suas Farpas de 1871, reaproveitada pelo autor para integrar Uma Campanha Alegre, o jovem Eça faz uma apreciação crítica à inauguração do novo mercado do peixe da cidade do Porto que, segundo ele, era um exagerado e despropositado edifício, pouco adequado à finalidade para que fora construído. O excerto é um pouco longo mas vale a pena revisitá-lo pelo humor e suprema ironia com que o processo crítico é construído, através de uma alegoria alimentícia:

"A Câmara Municipal do Porto, com uma nobre solicitude pelo peixe, para quem parece ser uma extremosa mãe, e receando, com um carinho assustado, que o peixe se constipasse, ou sofresse a indiscrição dos vizinhos, construiu-lhe uma praça fechada, com altas e fortes paredes, varandas, gabinetes interiores, corredores,

\footnotetext{
${ }^{20}$ Queirós, 1992:141.

${ }^{21}$ Queirós, s/d: 199.

${ }^{22}$ Queirós, 1981: 122.
} 
alcovas, casa bem reparada, quase um palacete. (...)” E continua, com suprema ironia, satirizando o elevado e inútil despesismo da obra: "era mandar tapetar a praça, colocar nos recantos sofás, e não esquecer um piano. O peixe deslizaria aí dias de grande doçura: os robalos estariam deitados em divãs de seda: o polvo teria livrarias para se instruir! O comprador seria introduzido por criados de libré. A peixeira conduzi-lo-ia a uma alcova, com as janelas cerradas, ergueria os cortinados de um leito, e mostraria inocentemente adormecidas, sob uma coberta de damasco - duas pescadinhas-marmotas!"23

Aliás, as crónicas deste período - todas elas, como é sabido, de grande ironia e corrosivo humor - espelham bem o valor cultural da alimentação. Num longo texto, publicado em março de 1872, sobre a educação feminina, o escritor aponta a alimentação como um dos vetores que muito contribui para a fragilidade do caráter das jovens burguesas de Lisboa:

"A menina solteira! Vejamos o tipo geral de Lisboa. É um ser magrito, pálido, metido dentro de um vestido de grande puff, com um penteado laborioso e espesso, e movendo os passinhos numa tal fadiga que mal se compreende como poderá jamais chegar ao alto do Chiado e da vida." ${ }^{24}$

A fragilidade doentia, fruto de uma educação conservadora, distorcida e anémica, é também resultado de uma dieta condicente: estas meninas "não comem: é raro ver uma menina alimentar-se de peixe, carne e vinho. Comem doce e alface. Jantam sobremesas. A gulodice do açúcar, dos bolos, das natas, é uma perpétua desnutrição." A gulodice é, como a moda, as leituras e o lar, uma das responsáveis pela fragilidade da mulher portuguesa - leia-se a burguesa urbana, vítima do atraso do país e de uma educação anacrónica e endogénica.

"Lisboa - diz Eça - é uma cidade doceira, como Paris é uma cidade intelectual. Paris cria a ideia, Lisboa o pastel. Daí a grande quantidade de doenças de estômago e de maus dentes. A deterioração pelo doce começa aos quatro anos. O sangue alimentado a massa, ovos, natas, dá estes corpos débeis e estas almas amolecidas." 25

Pretexto para a crítica moral, a doçaria nacional é aqui um símbolo de decadência que contrasta com a cidade luz, centro dessa Europa civilizada que tardava a transpor os Pirenéus. A dissolução social veiculada pelas referências à doçaria regressa em alguns momentos do romance O Primo Basílio, onde

\footnotetext{
${ }^{23}$ Queirós, s/d: 134.

${ }^{24}$ Queirós, s/d: 325.

${ }^{25}$ Queirós, s/d: 325.
} 
encontramos Alves Coutinho no jantar oferecido pelo Conselheiro Acácio - outra pérola da comensalidade queirosiana.

"Mas em presença dos doces que a Sra. Filomena dispôs sobre a mesa, o Alves Coutinho esquecera as mulheres, e, voltado para Sebastião, discutia gulodices. Indicava as especialidades: para os folhados, o Cocó! Para as natas, o Baltresqui! Para as gelatinas, o Largo de São Domingos! Dava receitas; contava proezas de lambarice, revirando os olhos:

- Porque - dizia — o docinho e a mulherzinha é o que me toca cá por dentro a alma!"26

Como explica José de Andrade, "a gula do empregado do Ministério do Reino por doces e a preferência pelos amores de serralho justificam, em certa medida, sua boca cheia de dentes estragados e suas atitudes pouco polidas à mesa" ${ }^{27}$. O mesmo é dizer que, em Eça, as cenas de mesa, os apetites e usos alimentares são recursos inestimáveis para a composição e figuração das personagens, delineando-lhes o carácter e indiciando vícios e comportamentos.

E é também com o recurso a uma descrição da montra de uma confeitaria de Lisboa que o narrador deste romance revela a decadência da média burguesia do reino. Sebastião e Julião, preocupados com a reputação de Luísa e com a ameaça pressentida pelas assíduas visitas de Basílio ao lar do amigo Jorge, encontram-se para conversar sobre o assunto. Menos relevante do que o teor do diálogo, é a esmagadora descrição da vitrine junto da qual as personagens estão que configura um espaço sócio-moral decadente:

"Estavam parados ao pé da confeitaria. Na vidraça, por trás deles, emprateleirava-se uma exposição de garrafas de malvasia com os seus letreiros muito coloridos, transparências avermelhadas de gelatinas, amarelidões enjoativas de doces de ovos, e queques de um castanho-escuro tendo espetados cravos tristes de papel branco ou cor-de-rosa. Velhas natas lívidas amolentavam-se no oco dos folhados; ladrilhos grossos de marmelada esbeiçavam-se ao calor; as empadinhas de marisco aglomeravam as suas crostas ressequidas. E no centro, muito proeminente numa travessa, enroscava-se uma lampreia de ovos medonha e bojuda, com o ventre de um amarelo ascoroso, o dorso malhado de arabescos de açúcar, a boca escancarada; na sua cabeça grossa esbugalhavam-se dois horríveis olhos de chocolates; os seus dentes de amêndoa ferravam-se numa tangerina de chila; e em torno do monstro espapado moscas esvoaçavam." ${ }^{28}$

\footnotetext{
${ }^{26}$ Queirós, s/d: 338.

${ }^{27}$ Andrade, 2014: 84.

${ }^{28}$ Queirós, s/d: 133.
} 
Contudo, serão os doces tradicionais portugueses a conquistar o sofisticado Jacinto ou o excêntrico Fradique: das compotas de pêssego da Joaninha de Cidade e as Serras, ao arroz doce - talvez a sobremesa mais citada na ficção queirosiana. Importava ao autor, nestas narrativas finisseculares, recuperar a gastronomia tipicamente nacional como marca positiva de uma identidade, à qual se opunha a sofisticação da haute cuisine française, grosseiramente importada como moda. Há um passo em $A$ Cidade e as Serras bem expressivo deste binómio tão característico de Eça: a antítese entre o genuíno e a cópia deturpada, tema que, como se sabe, é tratado em diversos romances do escritor. Zé Fernandes decide pedir ao ilustre cozinheiro francês do 202 dos Campos Elísios uma bela travessa de arroz-doce, à portuguesa, para deliciar Jacinto no dia de seu aniversário:

"mas quando o arroz-doce apareceu triunfalmente, que vexame! Era um prato monumental, de grande arte! $\mathrm{O}$ arroz, maciço, moldado em forma de pirâmide do Egito, emergia duma calda de cereja, e desaparecia sob os frutos secos que o revestiam até ao cimo onde se equilibrava uma coroa de Conde feita de chocolate e gomos de tangerina gelada! E as iniciais, a data, tão lindas e graves na canela ingénua, vinham traçadas nas bordas da travessa com violetas pralinadas! Repelimos, num mudo horror, o prato acanalhado. E Jacinto, erguendo o copo de champanhe, murmurou como num funeral pagão: - Ad Manes, aos nossos mortos!"29

Trata-se, no fundo, de valorizar a autenticidade em detrimento da imitação desadequada de importações francesas que o autor glosa e desenvolve no célebre texto "O Francesismo", escrito muito provavelmente em $1887^{30}$, em que demonstra com algum sarcasmo o processo de aculturação sofrido em Portugal pela cultura francesa, a começar pelo sistema educativo nacional:

"Não quero escrever uma página de memórias. Apenas mostrar, tipicamente, como eu, e toda a minha geração (exceptuando espíritos superiores, como Antero de Quental ou Oliveira Martins) nos tínhamos tornado fatalmente franceses no meio duma sociedade que se afrancesava e que, por toda a parte, desde as criações

${ }^{29}$ Queirós, s/d: 110.

${ }^{30}$ Não há certezas quanto à data de produção deste texto, publicado postumamente em Últimas Páginas. Segundo a argumentação de Guerra da Cal, baseada nas referências contidas no texto, o ensaio terá sido escrito em 1887: "Es un ensayo de alto interés bioliterario sobre cuya fecha cabe hacer una conjectura bastante aproximada, a base de dos referencias contenidas en el texto. (...) Pero como la otra referencia es a la novela de Zola, La Terre, que vio la luz en 1887, hay base adicional para datar en este último año la composición de este escrito." (Guerra da Cal, 1975: 361). Aliás é com base nesta suposta data que Carlos Reis explica o facto de este texto nunca ter sido publicado em vida do autor: em vésperas de partir para o consulado de Paris, para onde vai em 1888, não seria politicamente correto subscrever uma crítica tão dura e contundente como esta ao país que o acolheria (Reis, 1997: 24-26). 
do Estado até ao gosto dos indivíduos, rompera com a tradição nacional, despindo-se de todo o traje português, para se cobrir - pensando, legislando, escrevendo, ensinando, vivendo, cozinhando - de trapos vindos da França" ${ }^{31}$.

Também no texto inaugural da sua colaboração jornalística com a Gazeta de Notícias, o autor começa por comentar, com a sua já habitual ironia, a supremacia das culturas francesa e inglesa, insinuando mesmo que as outras culturas apenas se preocupam em enveredar por uma imitação servil, ao ponto de "cada cidade, cada nação, se [estar] esforçando por aniquilar a sua originalidade tradicional, nas maneiras e nos edifícios, desde os regulamentos de polícia até à vitrine dos joalheiros, - e dar-se a linha parisiense." ${ }_{32}$ Estas palavras significam uma ideia chave do pensamento queirosiano, nomeadamente da imagem que Eça projetava da França nos seus textos e que tem que ver com a forma como a cultura portuguesa, sobretudo desde o século XVIII, funcionou como uma espécie de cópia servil daquilo que se passava em França, centro irradiador do gosto, da literatura, da moda, das ideias e também da gastronomia.

Carlos da Maia, chegado de Paris depois de dez anos de ausência, traz consigo, além de um sentimento de vencidismo derrotista, o desejo especial de comer paio com ervilhas e só um jantar com amigos o obriga a uma corrida para apanhar o 'americano', na cena sobejamente conhecida que encerra o romance. As especialidades nacionais passam a preencher as cenas de mesa de narrativas como A Cidade e as Serras, A Ilustre Casa de Ramires e até mesmo a epistolografia de Carlos Fradique Mendes, sendo as eleitas pelos protagonistas, em detrimento dos cosmopolitas pitéus europeus, entendidos como a tradução em calão da Haute Cuisine.

É pela excelência da cozinha nacional que o snob e cosmopolita Jacinto é seduzido pela terra portuguesa. A personagem principal de $A$ Cidade e as Serras, saturado do progresso e da sofisticação que o seu $202 \mathrm{em}$ plena avenida dos Campos Elíseos lhe proporcionava, é conquistado pela ruralidade portuguesa em grande parte através da boca. Desde que chega ao seu país natal, Jacinto - que até então considerava inaceitável poder viver num submundo como aquele - é constantemente confrontado com a pureza da paisagem, a descontaminação dos ares, a beleza das serras do Douro e, claro está, com os novos paladares e odores da boa gastronomia nacional.

"E à noite o primeiro bródio da serra, com os pitéus vernáculos do velho Portugal! Jacinto sorria, seduzido: - Vamos a ver que cozinheiro me arranjou esse Silvério. $\mathrm{Eu}$ recomendei que fosse um soberbo cozinheiro português, clássico. Mas que

\footnotetext{
${ }^{31}$ Queirós, s/d.: 819.

${ }^{32}$ Queirós, 2002: 57.
} 
soubesse trufar um peru, afogar um bife em molho de moela, estas coisas simples da cozinha de França!...”33

Esta resistência inicial, típica de quem vem acostumado à sofisticada e aprimorada cozinha francesa, é muito rapidamente superada, já que o protagonista se vai deixando encantar pelos cheiros, pelas cores, pelos sabores da cozinha do velho Portugal. É um retorno às origens, um retorno ao mundo descontaminado e natural de um Portugal típico, onde o progresso ainda não tinha corrompido hábitos ou tradições. O jantar preparado por Melchior é bem a prova de que Jacinto começou por ser conquistado pelo estômago:

"Na mesa, encostada ao muro denegrido, sulcado pelo fumo das candeias, sobre uma toalha de estopa, duas velas de sebo em castiçais de lata alumiavam grossos pratos de louça amarela, ladeados por colheres de estanho e por garfos de ferro. Os copos, de um vidro espesso, conservavam a sombra roxa do vinho que neles passara em fartos anos de fartas vindimas. A malga de barro, atestada de azeitonas pretas, contentaria Diógenes. Espetado na côdea de um imenso pão reluzia um facalhão. (...) Jacinto ocupou a sede ancestral - e durante momentos (de esgazeada ansiedade para o caseiro excelente) esfregou energicamente com a ponta da toalha, o garfo negro, a fusca colher de estanho. Depois, desconfiado, provou o caldo, que era de galinha e rescendia. Provou - e levantou para mim, seu camarada de misérias, uns olhos que brilharam, surpreendidos. Tornou a sorver uma colherada mais cheia, mais considerada. E sorriu, com espanto. - Está bom! Estava precioso. Tinha fígado e tinha moela: o seu perfume enternecia: três vezes, fervorosamente, ataquei caldo. - Também lá volto! - exclamava Jacinto com uma convicção imensa. - É que estou com uma fome... Santo Deus! Há anos que não sinto esta fome" ${ }^{\text {"34. }}$

A mesma sedução encontramo-la numa das mais fascinantes e complexas criações queirosianas - Carlos Fradique Mendes. Poeta inédito inventado por Eça, figura excêntrica e cosmopolita, bem instalado na vida, colecionador de arte e homem viajado, Fradique centra-se em Paris, o "seu centro e o seu lar", e aí fica dependente da tecnologia e do progresso. No entanto, o regresso a Portugal, um pouco à maneira de um eterno touriste, leva-o a construir utopicamente uma imagem idílica do país: este será o local propício ao desfastio da civilização, uma espécie de coutada soalheira, enquistada no tempo, em que se preservam hábitos, tradições e costumes ancestrais, imunes ao progresso e à mudança: um povo manso e visto como mero elemento da paisagem, gente ingénua e submissa, com excelentes ares e belíssimas quintas, e, sobretudo, uma cozinha tradicional fascinante. Em carta a Madame de Jouarre (Carta XII), escrita de uma quinta do Minho, Fradique comenta:

\footnotetext{
${ }^{33}$ Queirós, s/d:131.

${ }^{34}$ Queirós, s/d:142-143.
} 
"Em palácio algum, por essa Europa superfina, se come na verdade tão deliciosamente como nestas rústicas quintas de Portugal. (...) Quem nunca provou este arroz de caçoula, este anho pascal candidamente assado no espeto, estas cabidelas de frango coevas da monarquia que enchem a alma, não pode realmente conhecer o que seja a especial bem-aventurança tão grosseira e tão divina, que no tempo dos frades se chamava a comezaina." 35

Tal como Carlos ou Jacinto, Fradique Mendes, apesar de muito crítico relativamente a diversos aspectos de Portugal, vê na gastronomia genuinamente nacional o sabor único e natural que os repastos cosmopolitas não lhe proporcionavam. Assim, a gastronomia portuguesa - a tradicional e original -, sobretudo nos últimos romances de Eça, é potenciada como elemento simbólico, de sentido ideológico claro: a valorização do país rural, a crítica à aculturação deficiente de modelos vindos de Paris ou Londres, nomeadamente à vida social da burguesia instalada.

Também nas suas narrativas breves, nomeadamente nos contos, Eça recorre à tópica alimentar para desenvolver sentidos narrativos relevantes, nomeadamente isotopias temáticas. Em 1884, o pecado capital de Frei Genebro está precisamente ligado à gula: o frade mancha a sua vida virtuosa para satisfazer o desejo de um eremita moribundo, a quem apetecia um naco de carne de porco.

"Pecado? Não, certamente! Aquele que, por tortura, recusa ao seu corpo um contentamento honesto, desagrada ao senhor. Não ordenava Ele aos seus discípulos que comessem as boas coisas da Terra? O corpo é servo; e está na vontade divina que as suas forças sejam sustentadas, para que preste ao espírito, seu amo, bom e leal serviço." ${ }^{36}$

Não hesita, portanto, o bom frade, em satisfazer o apetite do amigo moribundo, arrancando a sangue frio o pernil de um leitãozinho, que ficou no chão agonizante.

“- Já vai alourando o porquinho, irmão Egídio! A pele já tosta, meu santo!

Entrou enfim na choça, triunfalmente, com o assado que fumegava e rescendia, cercado de frescas folhas de alface. Ternamente, ajudou a sentar o velho, que tremia e se babava de gula." ${ }^{37}$

Embora apareça metaforizada neste conto, a gula como pecado capital é essencialmente caricaturada em Eça através da construção de alguns tipos.

\footnotetext{
${ }^{35}$ Queirós, s/d:197-98.

${ }^{36}$ Queirós, s/d: 110.

${ }^{37}$ Queirós, s/d: 111.
} 
Nenhum padre queirosiano é absolvido desse pecado, normalmente ostentado pelo ventre proeminente e por certos tiques gulosos. Veja-se como é apresentado o Cónego Dias em O Crime do Padre Amaro: "Era muito conhecido em Leiria. Ultimamente engordara, o ventre saliente enchia-lhe a batina; e a sua cabecinha grisalha, as olheiras papudas, o beiço espesso faziam lembrar as velhas anedotas de frades lascivos e glutões"; o abade da Cortegaça que "passava por ser o melhor cozinheiro da diocese", título que lhe era atribuído graças à fama da sua cabidela de caça.

"O excelente abade estava escarlate de satisfação. Era, como dizia o senhor chantre, um divino artista! Lera todos os «Cozinheiros Completos», sabia inúmeras receitas; era inventivo - e, como ele afirmava dando marteladinhas no crânio, «tinha-lhe saído muito petisco daquela cachimónia!» Vivia tão absorvido pela sua «arte» que lhe acontecia, nos sermões de domingo, dar aos fiéis ajoelhados para receberem a palavra de Deus, conselhos sobre o bacalhau guisado ou sobre os condimentos do sarrabulho. E ali vivia feliz, com a sua velha Gertrudes, de muito bom paladar também, com o seu quintal de ricos legumes, sentindo uma só ambição na vida - ter um dia a jantar o bispo!"38.

Não se pense, porém, que a gula é mácula restrita a sacerdotes. Em todos os seus grandes romances este pecado serviu a Eça para construir caricaturas interessantes, nem sempre figuras de grande relevo diegético mas que, no fundo, são elementos fundamentais do puzzle social construído progressivamente nas suas narrativas. A Viscondessa de Runa, em Os Maias "parecia mais gorda, toda acaçapada na cadeira, silenciosa, comendo sempre; e, a cada gole de Bucelas, refrescava-se languidamente com o seu grande leque negro e lentejoulado." ${ }^{9}$ Também Dona Felicidade, personagem afidalgada de $O$ Primo Basílio, solteirona frustrada, é apresentada como "muito bem nutrida", de "cara lisa e redonda, que, apesar de sofrer de dispepsia, não resiste aos doces de ovos e aos sorvetes". Juliana é descrita, desde o seu aparecimento no romance, como gulosa e lambareira, nutrindo "um desejo insatisfeito de comer, de petiscos, de sobremesas." Quase como um substituto sexual, a alimentação é, nestes casos, o modo de satisfação de mulheres solteironas e frustradas e uma componente fundamental da figuração de um certo tipo feminino ${ }^{40}$.

Como se de um dramaturgo se tratasse, o narrador queirosiano monta a cena - personagens à mesa -, compõe a cenografia e vai tecendo o discurso através do cruzamento das conversas e dos temas com a entrada dos diferentes

\footnotetext{
${ }^{38}$ Queirós, s/d: 111-112.

${ }^{39}$ Queirós, s/d: 64.

${ }^{40}$ Sobre as relações entre o ato de comer e notações de índole erótica e sexual, na obra de Eça, vejam-se: Lima, 1995: 715-721; Andrade, 2012: 33-45.
} 
manjares dos repastos, desde a sopa à sobremesa, deleitando-se com descrições pormenorizadas e muito sugestivas dos pratos, da comida, das bebidas, dos sabores e cheiros, das cores da louça, etc. Mas também dos comportamentos dos convivas: o modo de mastigar, de sorver, de beber... Esta não é, note-se, uma estratégia inocente, pois, através da comida e das referências alimentares, consegue o autor desconstruir a seriedade da sociedade de elite da época, desmascarando-a e dando dela uma imagem deformada e, como tal, mais verdadeira. Assinalem-se apenas dois jantares bem famosos que ilustram o que acaba de se concluir: em O Primo Basílio, o jantar oferecido pelo Conselheiro Acácio; e em Os Maias, o célebre Jantar do Hotel Central. Em ambos, as capacidades dramatúrgicas de Eça expõem, sem mediação, as personagens em cena: o que comem, como comem, os nomes das iguarias, as conversas, os comentários, as criadas ou criados, os espaços, a decoração, enfim, um conjunto de adereços significativos que remetem para a um arquétipo das representações da sociedade portuguesa.

Por vezes este processo chega a tocar o registo satírico e cómico, como ocorre em Alves E C . $^{i a}$ : no momento em que o protagonista descobre que estava a ser traído pelo seu melhor amigo, batem à porta trazendo a empada de fiambre e queijo que encomendara para o aniversário da mulher infiel. $\mathrm{Ou}$ quem não recorda a célebre avaria do elevador que, no conto "Civilização" e posteriormente em $A$ Cidade e as Serras, impede que Jacinto deleite os excelsos convivas com o raro peixe da Dalmácia, expressamente encomendado pelo Grão-Duque? A cena que provavelmente melhor poderá ilustrar esta estratégia é o célebre desfecho de Os Maias: Carlos e Ega, 10 anos depois do desenlace trágico dos amores incestuosos do protagonista, reencontram-se em Lisboa e fazem um balanço preocupante das suas vidas. Falharam a vida, fracassaram em tudo, são uns frustrados vítimas do descentramento e do diletantismo que afetaram a sua geração. Adotam com uma leveza espantosa a filosofia de abandono voluntário, segundo a qual nada mais valerá a pena, "não valia a pena dar um passo para alcançar coisa alguma na Terra (...) porque tudo se resolve em desilusão e poeira". No entanto, o jantar no Hotel Bragança e as saudades de um belo paio com ervilhas levam os dois amigos a uma corrida desenfreada para o 'americano'.

Em síntese, parece-nos que o estudo da gastronomia em Eça não pode ser redutível a um aspecto de fait-divers ou a um pormenor de secundária importância, nem tão pouco circunscrever-se às narrativas de maior fôlego. Falar da comensalidade em Eça implica que a entendamos como aspecto temático e estratégico, como bem o demonstraram já alguns autores. Ela serve para se compreender o desenvolvimento do enredo de alguns romances - como sucede, por exemplo, em Os Maias na projeção estratégica do Jantar do Hotel Central; ela permite a apresentação, caracterização e figuração das personagens; propicia o desenvolvimento de temas de natureza sociocultural; 
assinala a marcação de contrastes; e é frequentemente um instrumento de sedução. Por outro lado, ela representa aquilo que em Eça é tão característico: a estética do pormenor, a atenção ao detalhe, o comprazimento em tornar significativas todas as singularidades dos cenários descritos.

\section{Bibliografia Ativa}

Queirós, E. de (s/d), A Cidade e as Serras, Lisboa, Livros do Brasil.

Queirós, E. de (s/d), A Relíquia, Edição de Helena Cidade Moura, Lisboa, Livros do Brasil.

Queirós, E. de (1983), Correspondência, Leitura, Coordenação, Prefácio e Notas de Guilherme de Castilho, Lisboa, INCM, Vol.1.

Queirós, E. de (s/d), "Frei Genebro", Contos Lisboa, Livros do Brasil, pp. 107-120.

Queirós, E. de, (2000), O Crime do Padre Amaro, Edição Crítica de Carlos Reis e Maria do Rosário Cunha, Lisboa, INCM.

Queirós, E. de (s/d), “O Francesismo”, In: Últimas Páginas, Obras de Eça de Queiroz, Vol. II, Porto, Lello \& Irmão - Editores, pp. 813 - 827.

Queirós, E. de (1992), O Mandarim, Edição Crítica de Beatriz Berrini, Lisboa, INCM.

Queirós, E. de (2006), “O Manifesto d'Os Vencidos”, AA.VV., Os Vencidos da Vida, 1ªed., Porto, Fronteira do Caos, pp. 33-35.

Queirós, E. de (s/d), O Primo Basílio, Edição de Helena Cidade Moura, Lisboa, Livros do Brasil.

Queirós, E. de (1981), Páginas de Jornalismo, Edição de Aníbal Pinto de Castro, Porto, Lello \& Irmão Editores.

Queirós, E. de (2002), Textos de Imprensa IV. Da Gazeta de Notícias, Edição Crítica de Elza Miné e Neuma Cavalcante, Lisboa, INCM.

Queirós, E. de (s/d), Uma Campanha Alegre, Edição de Helena Cidade Moura, Lisboa, Livros do Brasil.

\section{Bibliografia Passiva}

Alves, D. (1992), Era Tormes e Amanhecia - Dicionário Gastronómico Cultural de Eça de Queiroz, Lisboa, Livros do Brasil.

Andrade, J. (2014), "Um jantar acaciano: na medida para a crítica gastronômica da burguesia lisboeta", Revista do Núcleo de Estudos de Literatura Portuguesa e Africana. Vol.6 N. ${ }^{12}$, abril, pp. 79-95.

Andradre, J. (2012), "Comer e comer: um verbo dos (re)cortes em O Crime do Padre Amaro", Pindorama. Revista Eletrônica Cientifica do IFBA, N. ${ }^{\circ}$, julho-dezembro, pp. 33-45.

Assis, M. (1994). "Eça de Queirós: O Primo Basílio", Obra Completa de Machado de Assis, Rio de Janeiro, Nova Aguilar, Vol. III (http://www.literaturabrasileira.ufsc.br/do cumentos/?action=download\&id=8274 Consultado em março de 2015). 
Berrini, B. (1995). Comer e Beber com Eça de Queiroz. Rio de Janeiro: Aguilar.

Berrini, B.; Modesto, M. L. (2014), Comer e Beber com Eça de Queiroz, Lisboa, Alêtheia Editores / Fundação Eça de Queiroz.

Guerra Da Cal, E. (1975), Lengua y Estilo de Eça de Queiroz - Apêndice Bibligrafía Queirociana sistemática y anotada e iconografia artística del hombre y la obra, Tomo 1\%, Coimbra, Imprensa da Universidade de Coimbra.

Lima, I. P. (1995), "Fulgurações e Ofuscações de Eros: O Primo Basilio", In: Anais do III Encontro Internacional de Queirosianos, 150 Anos com Eça de Queirós, S. Paulo, USP, pp. 715-721.

Maciel, M. E. (2002). "Olhares antropológicos sobre a Alimentação”, In: Canesqui, A.; Garcia, R. (orgs.), Antropologia e nutrição: um diálogo possível [online]. Rio de Janeiro: Editora FIOCRUZ, SciELO Books <http://books.scielo.org>.

Montanari, M.; Frandrin, J-L. (1996), Histoire de l'Alimentation, Paris, Fayard.

Reis, C. (1997), Eça de Queirós Consul de Portugal à Paris 1888-1900, Paris, Centre Culturel C. Gulbenkian.

Rocha, A. C. (1988). “Alusões Alimentares”, In: Matos, C. (Org.), Dicionário de Eça de Queiroz, Lisboa, Caminho.

Seixo, M. A. (2014), "Os sabores da literatura ou: como a gastronomia se apoia nos modos de dizer", Revista do Núcleo de Estudos de Literatura Portuguesa e Africana. Vol.6 N.o12, abril, pp. 15-35.

Vilela, A. L. (2010), "Le corps et le roman: l'allusion culinaire et la représentation des repas dans Os Maias, de Eça de Queirós", In: Buschinger, D. (ed.), Banquets et convivialité. Actes du Colloque international des 3, 4 et 5 mars à la Maison de la Culture d'Amiens, pp. 173-178.

Vilela, A. L. (2012), "Alguns factores de erotização discursiva n'Os Maias, de Eça de Queirós”, In: Vilela, A. L., Esteves, E. e Marçalo, M. J., Ultrapassando Fronteiras. Estudos de Literatura e Cultura Lusófonas, col. LITERATURA 5, Edição Centro de Estudos em Letras, Universidade de Évora, pp. 153-160. 